\title{
Skin cancer in rural workers: nursing knowledge and intervention
}

\author{
Câncer de pele em trabalhadores rurais: conhecimento e intervenção de enfermagem \\ Cáncer de piel en trabajadores rurales: conocimiento e intervención de enfermería
}

\author{
Marta Regina Cezar-Vaz ${ }^{1}$ Clarice Alves Bonow ${ }^{1}$, Diéssica Roggia Piexak², Sirlei Kowalczyk ${ }^{3}$, Jordana Cezar Vaz ${ }^{4}$, Anelise \\ Miritz Borges ${ }^{3}$
}

\footnotetext{
${ }^{1}$ Universidade Federal do Rio Grande, Escola de Enfermagem, Rio Grande, RS, Brazil.

${ }^{2}$ Universidade Federal do Rio Grande, Escola de Enfermagem, Programa de Pós-Graduação em Enfermagem, Rio Grande, RS, Brazil.

${ }^{3}$ Unimed Litoral Sul, Rio Grande, RS, Brazil.

${ }^{4}$ Universidade José do Rosário Vellano, Alfenas, MG, Brazil.
}

\begin{abstract}
Objective: To identify the exposure of rural workers to the sun's ultraviolet radiation and pesticides; to identify previous cases of skin cancer; and to implement clinical and communicative nursing actions among rural workers with a previous diagnosis of skin cancer. Method: Observational-exploratory study conducted with rural workers exposed to ultraviolet radiation and pesticides in a rural area in the extreme south of Brazil. A clinical judgment and risk communication model properly adapted was used to develop interventions among workers with a previous history of skin cancer. Results: A total of $123(97.7 \%)$ workers were identified under conditions of exposure to the sun's ultraviolet radiation and pesticides; seven $(5.4 \%)$ were identified with a previous diagnosis of skin cancer; four $(57.1 \%)$ of these presented potential skin cancer lesions. Conclusion: This study's results enabled clarifying the combination of clinical knowledge and risk communication regarding skin cancer to rural workers.
\end{abstract}

\section{DESCRIPTORS}

Skin Neoplasms; Rural Workers; Occupational Risks; Oncology Nursing; Clinical Competence; Health Communication.
Correspondence Addressed to:

Marta Regina Cezar-Vaz

Rua General Osório, n/nº - Campus da Saúde Área Acadêmica

CEP 96203-900 - Rio Grande, RS, Brazil

cezarvaz@vetorial.net 


\section{INTRODUCTION}

Skin cancer is present all over the world ${ }^{(1)}$ and its subtypes include basal cell carcinoma, squamous cell carcinoma and melanoma ${ }^{(1-2)}$. Basal cell and squamous cell carcinomas are the most common and are characterized by non-melanoma skin cancer, most frequently affecting fair-skinned people due to excessive sun exposure. These types of skin cancer present a good prognosis and a high rate of cure if treated early ${ }^{(1-2)}$. It is estimated that non-melanoma skin cancer is the most common form of cancer worldwide with 80,000 new cases/year in Canada in $2010^{(3)}, 1$ million in the USA in $2013^{(4)}$, and 182,000 cases in Brazil in 2014 $4^{(1)}$. The incidence of non-melanoma skin cancer in higher among men, especially in the south of Brazil (159.51/100,000 cases). The estimated risk for women is 86.03 per 100,000 cases in the same region ${ }^{(1)}$. Melanoma is a less frequent type, but the risk factors are the same: fair-skinned people with excessive sun exposure. This type of cancer is strongly linked to high doses of intermittent sun radiation that cause burns, especially at an early age ${ }^{(1)}$. In the United States, it is estimated there is an incidence of 76,000 cases $^{(4)}$ while in Brazil, the incidence rate is 2,960 new cases among men and 2,930 among women ${ }^{(1)}$. The South is the region with the highest incidence of melanoma in Brazil: 920 cases among men and 880 cases among women. Melanoma is the least common but the most severe type of skin cancer. Studies conducted in Holland ${ }^{(5)}$ and in the United States ${ }^{(6)}$ report there is an increase in mortality rates due to this disease. Specifically, the basal cell and squamous cell types are related to occupational exposure to physical risk: the sun's ultraviolet (UV) radiation ${ }^{(7)}$. Sun exposure occurs in different occupations such as welders, fishermen, police officers, physical education teachers, and rural workers; the last are the focus of this study ${ }^{(8-10)}$. Other evidence associates skin cancer with occupational exposure to chemical compounds. Arsenic is shown as a compound that may be related to the development of skin cancer, especially when associated with UV radiation ${ }^{(11)}$, as is the case of farm workers. These workers are in contact with both physical and chemical risks because arsenic is a compound used in pesticides ${ }^{(12)}$.

Such evidence leads public health agencies to implement interventions that involve preventive measures, detection of cases, and care provided to individuals affected by skin cancer. In this study, we emphasize risk communication combined with clinical actions (judgment and decisionmaking based on best practices) to implement interventions among the rural workers participating in this study. Based on this theoretical and practical intention, we chose clinical and communicative nursing action, which is based on the concept of risk communication using the structure of clinical knowledge. Risk communication in the health field is an intervention with robust efficacy to improve a variety of healthy behaviors ${ }^{(13)}$. Communication based on judgment, which is established on clinical knowledge, provides a range of evidence for nursing workers to decide for the best practice in the prevention of cases and to provide care to individuals affected by skin cancer. Such evidence is a result of research addressing the risks, detection, diagnosis ${ }^{(4,7-8)}$ and prevention of skin cancer in the rural population ${ }^{(9,14)}$. Note also that screening methods are necessary to detect the disease among rural workers ${ }^{(9)}$. Studies conducted by nurses evidence the need to search for evidence to help nursing workers construct resolving actions through clinical knowledge in situations of skin cancer ${ }^{(10)}$.

From this perspective, this study's objectives were: to identify the exposure of rural workers to UV radiation from the sun and to pesticides; to identify previous history of skin cancer; and to apply clinical and communicative nursing actions among rural workers with a previous diagnosis of skin cancer. Clinical and communicative action helps nurses in the process of preventing exposure of rural workers to the potential risk of developing skin cancer, as well as minimizes the recurrence of the disease as these individuals, due to the nature of their occupation, are continually exposed to UV radiation and pesticides, which are physical and chemical risks, respectively, associated with skin cancer.

\section{METHOD}

This observational-exploratory study was conducted with rural workers from a city in the extreme south of the State of Rio Grande do Sul, Brazil. The study's population was composed of rural workers exposed to UV radiation and pesticides, as physical and chemical risks, which are associated with the onset of skin cancer. The following inclusion criteria were used to select the sample: workers living in the rural area where work is performed; being 18 years old or older; working in horticultural farming. Those not working with agriculture in the period of data collection were excluded. Note that the overall number of rural workers was not provided by official sources, state or city agencies linked to the assistance provided to rural workers (Rural Workers Union, Technical Assistance and Rural Extension Company, and the city's Department of Agriculture). For this reason, we opted for a non-probabilistic convenience sample. Sample size was calculated using the StatCalc tool from EpiInfo 6.04, considering the general population, i.e., without having knowledge concerning the specific rural population, with a confidence level of $95 \%$, which resulted in 179 workers. To compose the sample, a house-to-house search was implemented to find workers in the study's rural area. A minimum of five failed attempts to contact workers in their homes was considered to characterize loss or refusal when the worker manifested no interest in participating in the study. Considering losses (17), refusals (25) and the exclusion of 19 individuals who did not work with agriculture, the sample was composed of 130 rural workers in horticultural farming.

The study design, observational-exploratory, was based on a clinical judgment and decision-adapted model, which implies assessing alternatives (judgment) and choosing one (decision) ${ }^{(15)}$ through clinical and communicative nursing action. Studies addressing collective behavior on skin cancer prevention, especially, but not exclusively ${ }^{(12)}$, those assessing non-melanoma skin cancers ${ }^{(4,7,10)}$, addressing factors associated with skin cancer ${ }^{(7,9)}$, and studies of screening, treatment and follow-up to avoid recurrences ${ }^{(4,10,14,16)}$, were used to support the development of this study. From this analyti- 
cal perspective, this study was divided into two stages. The first stage (clinical judgment-diagnosis, description, assessment and prediction) was conducted from March to November 2013. A total of 130 rural workers were interviewed using a structure questionnaire (procedure 1) containing questions that characterized the individuals (sex, age, race and schooling), occupational variables (daily time working and years of working), previous diagnosis of skin cancer, and exposure to UV radiation exposure (type of activity, personal protective equipment, and months with more intense work), and pesticides (application and personal protective equipment). This questionnaire has been used in other studies ${ }^{(17-18)}$ and was adapted for this study through a pilot study conducted with ten workers who were not included in the study sample. At this point, the workers exposure to physical (UV radiation) and chemical risks (pesticides) was identified through diagnosis and description and those with previous diagnosis of skin cancer were identified by self-report. Clinical judgment continued by assessing data concerning exposure of rural workers and prediction that, with continuous exposure, workers should receive communication about the risks and take preventive measures against skin cancer. Studies identify clinical evidence regarding the risk of recurrence of skin cancer in the population of rural workers ${ }^{(5,7-8)}$. This assumption determined what would be the priority for the next stage. The second stage (clinical decision - intervention, target, date, communication, organization, and understanding) included collecting data from March to August 2014. The targets of the intervention were the workers who reported a previous diagnosis of skin cancer. Clinical assessment of each of the workers was conducted through individual interviews using a structured questionnaire (procedure 2), seeking data concerning the previous diagnosis of skin cancer. Data collected included a detailed report of previous skin cancer (type of cancer, number and site(s) of lesions, treatment, follow-up in a health service, and family history of skin cancer). Establishing the best point in time (date) to perform the intervention with this group was based on the premise that workers were exposed to physical and chemical risks in the rural work environment (UV radiation and pesticides, respectively) and therefore, were at the risk of recurrence $^{(19)}$, which is considered a clinically relevant marker for the implementation of an intervention.

To seek more evidence about what would be the best sort of communication to be used with these individuals, we systematically observed (procedure 3 ) these workers (who had reported previous skin cancer) in loco using a checklist including activities performed and protective measures used against UV radiation and pesticides. This process was always performed with the presence of two observers. Observations took place without previously scheduling a specific time; that is, the observers addressed the rural workers when they were already working in the field. This strategy was intended to reduce bias since, otherwise, workers could prepare in advance to receive the observers. Observation per worker took an average of 50 minutes. Communication on the part of researchers took place through dialogued explanation provided at the workers' homes in the presence of their spouses/partners.
Evidence of clinical knowledge and prevention against skin cancer were the bases of the communication process.

Organization of the service in regard to the development of clinical and communicative nursing action included the researchers helping the individuals to become familiar with the public service, represented here by the outpatient surgery center of a university hospital. Understanding (detail) of cases was accomplished by photographic screening the skin of the rural workers who had reported previous diagnosis in order to identify lesions indicative of skin cancer. The lesions were assed by a group composed of nurses and a plastic surgeon specializing in skin lesions. The lesions indicating skin cancer were classified according to the Union for International Cancer Control (UICC) ${ }^{(20)}$, American Cancer Society ${ }^{(2)}$, the Brazilian National Cancer Institute (INCA) ${ }^{(1)}$, and the Fitzpatrick Scale ${ }^{(21)}$. After assessment, the lesions with characteristics that indicated potential recurrence of cancer were removed. The stages composed a process coordinated by clinical knowledge and knowledge of risk communication. In this set of procedures, each procedure has its own description but is not isolated from other procedures; that is, the stages are combined with each other in the process of judgment and clinical decision-making.

Data analysis included descriptive measures and frequencies of the variables using the Statistical Package for the Social Sciences (SPSS), version 19.0. Cronbach's alpha (measure of internal consistency of responses) was used to verify whether data were reliable, which confers greater robustness to the study. Cronbach's alpha was equal to 0.86 , between 0.80 and 0.90 , i.e., within the expected parameters ${ }^{(22)}$, which confirms the reliability of the instrument applied to the workers for what was proposed in this study.

Guidelines presented by Resolution 466/2012, Brazilian Council of Health that regulates research involving human subjects were followed. The study project was submitted to and approved by the Institutional Review Board and the National Council of Research Ethics (CONEP) under process No. 026/2013. All the participants were informed of the study's objectives and signed two copies of free and informed consent forms, in both the first and second stages, and were ensured confidentiality of their identities and information provided.

\section{RESULTS}

The study's first stage - Nursing clinical judgment included 130 rural workers aged 55.67 years old on average, with standard deviation (SD) \pm 13.05 ; most were men (60.8\%), Caucasian (98.4\%), with incomplete primary education (78.5\%). Average time in this occupation was 40.62 years $(\mathrm{SD} \pm 15.70)$, with 8.5 daily working hours $(\mathrm{SD} \pm 3.5)$.

The diagnosis and description steps of the clinical judgment revealed that workers were exposed to UV radiation because they performed activities such as soil preparation ( $\mathrm{n}=108 ; 83.1 \%)$, crop planting $(\mathrm{n}=125 ; 96.2 \%)$, and harvesting agricultural products $(n=127 ; 97.7 \%)$. For 70 workers $(53.8 \%)$, December was the month of the most intense work; 78 (60\%) workers reported that January was the most intense; for $75(57.7 \%)$ February was the most intense; 
while 58 (44.6\%) workers reported the most intense working month was March. Note that the percentage concerning the months with the most intense rural work was obtained from the set of interviewees based on answers provided to
(14.3\%) self-reported melanoma. Only two (28.6\%) workers performed follow-up in the health unit. More details concerning the previous skin cancer lesions of these rural workers are provided in Table 1.

Table 1 - Details concerning the previous skin cancer lesions self-reported by rural workers - city in the extreme south of the state of Rio Grande do Sul, Brazil 2014.

\begin{tabular}{|c|c|c|c|c|c|c|}
\hline Cases & $\begin{array}{l}\text { Type of cancer } \\
\text { diagnosed }\end{array}$ & $\begin{array}{c}\text { No. of diagnosed } \\
\text { lesions }\end{array}$ & Site of lesions & Treatment & Follow-up & $\begin{array}{l}\text { Family } \\
\text { history }\end{array}$ \\
\hline 1 & Do not know & One & Nose & Surgery & No & Do not know \\
\hline 2 & Do not know & One & Lip & Surgery & No & Yes \\
\hline 3 & Do not know & One & Forearm & Surgery & No & Yes \\
\hline 4 & Do not know & One & Face & Surgery & Yes & Do not know \\
\hline 5 & Do not know & One & Eyelid & Surgery & No & Yes \\
\hline 6 & Do not know & One & External ear & Surgery and medication & Yes & Yes \\
\hline 7 & Melanoma & One & Nose & Surgery & No & Yes \\
\hline
\end{tabular}

each of the multiple choice responses. The rural workers reported using personal protective equipment against UV radiation to perform agricultural activities that included waterproof boots $(n=122 ; 93.8 \%)$, brimmed hat $(n=108 ; 83.1 \%)$, sunscreen $(n=75 ; 57.7 \%)$, gloves $(n=74 ; 56.9 \%)$, moisturizer $(n=50 ; 38.5 \%)$, overalls $(n=26 ; 20 \%)$, cap $(n=12 ; 9.2 \%)$, and long sleeves shirt $(n=1 ; 0.8 \%)$. A total of $73(56.2 \%)$ workers self-reported the application of pesticides and the use of waterproof boots $(n=19,14.6 \%)$, water-repellent coat $(n=16$; $12.3 \%)$, gloves $(n=15,11.5 \%)$, water-repellent pants $(n=14$, $10.8 \%)$, face shield $(n=12,9.2 \%)$, mask $(n=9,6.9 \%)$, protective hood $(n=8 ; 6.2 \%)$, helmet $(n=7 ; 5.4 \%)$, brimmed hat $(n=6$, $4.6 \%)$, and long-sleeved clothing $(n=3,2.3 \%)$. These results show that 127 workers $(97.7 \%)$ are exposed to working conditions that favor the development of skin cancer, i.e., UV radiation and the application of pesticides. We also identified that seven $(5.4 \%)$ out of 130 workers presented a previous diagnosis of skin cancer. This information enabled assessment and prediction regarding exposure to risks for these workers, risks that could lead to the onset of skin cancer or its recurrence, for those with prior history of the disease.

Therefore, an intervention was devised during the second stage (Nursing clinical decision) to intensify preventive measures and diagnose skin cancer early. The target of the intervention included seven individuals with prior history of skin cancer, as previously mentioned. The intervention was performed with each of these individuals through an individual interview, investigation of previous diagnosis of skin cancer, and observation of workers. These seven individuals with previous diagnosis of skin cancer were 65.83 years old on average ( $\mathrm{SD} \pm 11.78)$; predominantly male $(\mathrm{n}=5 ; 71.42 \%) ; 100 \%$ had fair skin, with Fitzpatrick II phonotype (sun-sensitive skin); and incomplete primary school. They had worked for an average of 50.86 years $(\mathrm{SD} \pm 16.37)$ and 10 daily working hours on average $(\mathrm{SD} \pm 4.32)$. All these individuals were exposed to $\mathrm{UV}$ radiation and pesticides and were included in the group of workers assessed in the first stage.

In the sequence - clinical investigation of previous diagnosis of skin cancer - six (85.7\%) individuals were not able to report the type of cancer diagnosed, while one worker
Overall, observation of the rural workers took 470 minutes and included seven workers with a previous diagnosis of skin cancer. The purpose of the observation was to seek risk situations and the use of preventive measures. In regard to these workers' activities, we observed the individuals in activities that involved sun exposure, such as soil preparation, harvesting of agricultural products, planting crops, and cleaning ditches around the beds. The workers were observed in the morning, between $10 \mathrm{am}$ and $12 \mathrm{pm}$, and in the afternoon between $2 \mathrm{pm}$ and $4 \mathrm{pm}$. The equipment used by the workers during these activities included waterproof boots $(n=5$; $71.4 \%$ ), overalls ( $n=1 ; 14.2 \%)$, and brimmed hat ( $n=1 ; 14.2 \%)$. In addition to these garments, the workers also protected themselves with caps $(n=5 ; 71.4 \%)$, berets $(n=1 ; 14.2 \%)$, long sleeves $(n=6 ; 85.7 \%)$, pants $(n=5 ; 71.4 \%)$, and close-toed shoes $(n=2 ; 28.5 \%)$. One (14.2\%) worker wore shorts to work and two $(28.5 \%)$ were observed wearing sandals. Note that there were no applications of pesticides in the period. Selfreported and observed data are not intended for comparison because self-reported information referred to more general behavior, while observation focused on a specific behavior and occasional specific times. Observation, however, specifically provided greater evidence of the fragility of individual protection among the seven individuals with previous diagnosis of skin cancer as the results show.

Organization (contacting the health service) and clinical understanding (detail) of cases included screening the skin of the seven rural workers who reported previous diagnosis in order to identify potential lesions indicative of skin cancer in the sites most exposed to UV radiation (upper limbs, hands, head, neck and face). Such a procedure, performed by a nurse using the photographic screening technique ${ }^{(2)}$, indicated that five $(71.5 \%)$ of these workers presented potential skin cancer lesions, one worker (14.3\%) did not present lesions that indicated skin cancer, while another (14.3\%) chose not to be screened. A medical expert conducted a clinical and surgical assessment after these lesions were identified. Removal (excision) of lesions and biopsies were recommended for four workers (57.1\%), all of whom consented and confirmed scheduling in the surgery outpatient center of a university 
hospital. Two workers (28.5\%) attended the surgical center on the day scheduled for the procedure. Details regarding the lesions identified and surgically removed are presented in Table 2.

Table 2 - Detail of lesions assessed in the rural workers who self-reported skin cancer - City in the extreme south of the state of Rio Grande do Sul, Brazil 2014.

\begin{tabular}{|c|c|c|c|c|c|c|c|c|c|c|}
\hline Cases & Sex & Age & Site & Symmetry & Edge & Color & $\begin{array}{l}\text { Dimension } \\
(\mathrm{mm})\end{array}$ & Observation & Excision & Pathological exam \\
\hline \multirow{2}{*}{1} & \multirow{2}{*}{$\mathrm{F}$} & \multirow{2}{*}{44} & $\begin{array}{l}\text { C44.4 [Neck } \\
\text { skin]* }\end{array}$ & Asymmetric & Irregular & $\begin{array}{l}\text { Above } \\
\text { two } \\
\text { shades }\end{array}$ & 5 & $\begin{array}{l}\text { Bulging with } \\
\text { pigmented } \\
\text { center }\end{array}$ & Performed & $\begin{array}{c}\text { - Intradermal } \\
\text { melanocyte nevus } \\
\text { - Surgical margins free }\end{array}$ \\
\hline & & & $\begin{array}{l}\text { C44.7 [Skin } \\
\text { of lower } \\
\text { limbs]* }\end{array}$ & Asymmetric & Irregular & $\begin{array}{l}\text { Above } \\
\text { two } \\
\text { shades }\end{array}$ & 4 & $\begin{array}{l}\text { Pigmented } \\
\text { center }\end{array}$ & Performed & $\begin{array}{c}\text { - Compound } \\
\text { melanocyte nevus } \\
\text { - Surgical margins free }\end{array}$ \\
\hline \multirow{2}{*}{2} & \multirow{2}{*}{ M } & \multirow{2}{*}{69} & $\begin{array}{l}\text { C44.3 [Face } \\
\text { skin]* }^{*}\end{array}$ & Asymmetric & Irregular & $\begin{array}{l}\text { Above } \\
\text { two } \\
\text { shades }\end{array}$ & 15 & Bulging & Performed & $\begin{array}{l}\text { - Hypertrophic actinic } \\
\text { keratosis on skin with } \\
\text { intense photodamage } \\
\text { - Surgical margins free }\end{array}$ \\
\hline & & & $\begin{array}{l}\text { C44.3 [Face } \\
\text { skin]* }^{*}\end{array}$ & Asymmetric & Irregular & $\begin{array}{l}\text { Above } \\
\text { two } \\
\text { shades }\end{array}$ & 5 & Bulging & Performed & $\begin{array}{c}\text { - Actinic keratosis } \\
\text { on skin with intense } \\
\text { photodamage } \\
\text { - Surgical margins free }\end{array}$ \\
\hline \multirow[b]{2}{*}{3} & \multirow[b]{2}{*}{ M } & \multirow[b]{2}{*}{76} & $\begin{array}{l}\text { C44.3 [Face } \\
\text { skin]* }\end{array}$ & Asymmetric & Irregular & $\begin{array}{l}\text { Above } \\
\text { two } \\
\text { shades }\end{array}$ & 4 & Bulging & $\begin{array}{l}\text { Indicated but } \\
\text { not performed }\end{array}$ & - \\
\hline & & & $\begin{array}{l}\text { C44.0 [Lip } \\
\text { skin]* }\end{array}$ & Asymmetric & Irregular & $\begin{array}{l}\text { Above } \\
\text { two } \\
\text { shades }\end{array}$ & 2 & - & $\begin{array}{l}\text { Indicated but } \\
\text { not performed }\end{array}$ & - \\
\hline \multirow{2}{*}{4} & \multirow{2}{*}{$\mathrm{F}$} & \multirow{2}{*}{53} & $\begin{array}{l}\text { C44.6 [Skin } \\
\text { of upper } \\
\text { limbs]* }\end{array}$ & Symmetric & Regular & $\begin{array}{l}\text { Above } \\
\text { two } \\
\text { shades }\end{array}$ & 5 & Bulging & $\begin{array}{l}\text { Indicated but } \\
\text { not performed }\end{array}$ & - \\
\hline & & & $\begin{array}{l}\text { C44.3 [Face } \\
\text { skin]* }^{*}\end{array}$ & Asymmetric & Irregular & $\begin{array}{l}\text { Single } \\
\text { shade }\end{array}$ & 15 & $\begin{array}{c}\text { Typical } \\
\text { lesion from } \\
\text { sun exposure }\end{array}$ & $\begin{array}{l}\text { Indicated but } \\
\text { not performed }\end{array}$ & - \\
\hline \multirow[b]{2}{*}{5} & \multirow[b]{2}{*}{ M } & \multirow[b]{2}{*}{49} & $\begin{array}{l}\text { C44.3 [Face } \\
\text { skin]* }^{*}\end{array}$ & Asymmetric & Irregular & $\begin{array}{l}\text { Single } \\
\text { shade }\end{array}$ & 5 & - & $\begin{array}{l}\text { Referred to an } \\
\text { ophthalmologist }\end{array}$ & - \\
\hline & & & $\begin{array}{l}\text { C44.6 [Skin } \\
\text { of upper } \\
\text { limbs]* }\end{array}$ & Symmetric & Irregular & $\begin{array}{l}\text { Single } \\
\text { shade }\end{array}$ & 10 & - & $\begin{array}{l}\text { Excision not } \\
\text { indicated }\end{array}$ & - \\
\hline $6^{* *}$ & M & 81 & - & - & - & - & - & - & - & - \\
\hline $7 * * *$ & $M$ & 60 & - & - & - & - & - & - & - & - \\
\hline
\end{tabular}

* Lesion classified as T1 - Primary tumor with a dimension of $2 \mathrm{~cm}$ or less; NX - regional lymph nodes cannot be assessed; MX - presence of distant metastasis cannot be assessed. ${ }^{* *}$ The interviewee did not present lesions indicative of skin cancer. ${ }^{* * *}$ The interviewee chose not to participate in the screening process.

\section{DISCUSSION}

This study's results corroborate the findings of other studies addressing the potential of skin cancer being triggered in population groups under similar occupational and clinical conditions, such as: average age because skin cancer is more frequent among male individuals ${ }^{(1)}$ aged above 50 years of age ${ }^{(2,19)}$, a profile similar to that found in other countries such as the United States ${ }^{(2)}$; continuous and cumulative exposure (working time) to UV radiation and contact with pesticides ${ }^{(3,7-9,12)}$, which are the working conditions experienced by men and women associated with the development of recurrence of the disease ${ }^{(11,19)}$; the study setting is located in the extreme south of Rio Grande do Sul, which is one of the Brazilian states located in the south with the highest incidence of non-melanoma skin cancer among men ${ }^{(1)}$.
Note that only one worker, out of the seven workers with a previous diagnosis of the disease, was able to report the type of skin cancer he was diagnosed with; melanoma. The two other workers monitored with clinical and surgical screening had their lesions removed and pathological exams were performed after excision. The pathological exams indicated melanocytes nevi and actinic keratosis.

Plausible evidence is presented by studies ${ }^{(7,10-12)}$ addressing specific conditions of exposure to UV radiation and pesticides as being risks associated with the development of skin cancer. Such evidence is demonstrated in one study conducted with rural workers in farmers' markets in the United States, which suggests that most farming workers who took part in the study were concerned with skin cancer risks and were aware of the importance of using protective measures. Personal actions, however, implementing appropriate safety 
measures against sun radiation need to be improved ${ }^{(16)}$. The reason is that exposure of these workers to UV radiation is much greater than that experienced by other types of workers because rural workers work outdoors ${ }^{(14)}$. In addition to sun exposure, one study conducted in England ${ }^{(23)}$ associates contact with pesticides with the onset of diseases, such as melanoma cancer, testicular cancer, and multiple myeloma.

Another aspect relevant to UV radiation and pesticide exposure involves the use of inappropriate personal protective equipment, such as wearing caps instead of brimmed hats ${ }^{(24)}$ and applying pesticides without appropriate protection ${ }^{(25)}$, according to this study's findings. Different studies indicate that encouragement to wear appropriate equipment is linked to greater knowledge concerning the disease, which may ease positive changes in the behavior of farm workers ${ }^{(14,16)}$. Observation of the group of seven workers during the risk communication process revealed there is partial adherence to the use of personal protective equipment. These data reinforce the idea that preventive measures are important, but not sufficient to change behavior, especially because rural workers may, over the course of the years of their working routine, acquire unsafe behavior toward UV radiation and pesticides ${ }^{(26)}$.

Interventions that take into account demographic, occupational and clinical characteristics such as clinical and communicative nursing action, bring about positive results in terms of the improved use of preventive and safety measures among workers ${ }^{(14,16)}$. One study conducted with other professionals - engineers-showed advancement in preventive behavior (the use of sunscreen) after educational intervention ${ }^{(26)}$. From this perspective, systematic educational action can be implemented in the future among the participants of this study. It is known that when workers believe they are susceptible to diseases, they become more willing to take preventive measures ${ }^{(14,26)}$. Based on this evidence we started with an already established diagnosis to deepen clinical and communication nursing action. There is also evidence ${ }^{(19)}$ that a previous diagnosis of skin cancer increases the likelihood of recurrence, since primary cancer occurs because of the uncontrolled division of cells due to gene mutation. Continuous mutations allow malignancy to spread throughout the body, which characterizes metastasis leading to secondary cancers. One study conducted with men and women with the diagnosis of melanoma skin cancer indicated for this group a moderate increase in the likelihood of women having lung and breast cancer and in the likelihood of men and women developing melanoma ${ }^{(19)}$. It shows the relevance of this disease for populations working in similar conditions, specifically within the academic proposal developed in this study.

After excision, the pathological exams of the workers' lesions indicated melanocytes nevi and actinic keratosis. Note that actinic keratosis is the most common precancerous lesion, which is composed of proliferative skin neoplasia, transformed keratinocytes that develop as a result of chronic UV radiation ${ }^{(2)}$, which is in accordance with what was found in this study; the pathological result concerning one of the workers indicated lesion with intense photodamage. This specific evidence corroborates existing knowledge concerning the incidence of the disease to be highest among men since men tend to spend longer periods in sun exposure $^{(1-2)}$ given their working conditions; those results are comparable to this study's findings.

In regard to melanocyte nevus, there is evidence showing that the preexistence of this type of lesion may develop into melanoma ${ }^{(27-28)}$. On the other hand, evidence does not facilitate confirming the diagnosis of the emergence of melanoma from a melanocyte nevus. Evidence from historical series of clinical cases indicates that the likelihood is from $18 \%$ to $85 \%{ }^{(28)}$. A study conducted with 397 people diagnosed with melanoma reports that only 37 (9.3\%) cases were histologically associated with melanocyte nevus. The estimate for the population in general is that from $2 \%$ to $8 \%$ of people present dysplastic nevi, that is, nevi that are more frequently associated with melanoma ${ }^{(27)}$.

This evidence justified the screening conducted in this study with the workers who self-reported the disease and remained exposed to skin cancer risks, as screening enhances the early detection of cancer lesions, as was the case in this study. Screening to differentiate the types of skin lesions, to identify the melanoma type, for instance, is important given the lethal potential of lesions if not detected and removed early, as well as because there is a possibility to differentiate the benign nevus that may be confused with malignant ones if a pathological exam is not performed.

\section{CONCLUSION}

This study revealed that 127 (97.7\%) of the rural workers were exposed to physical and chemical risks - UV radiation and pesticides - and identified seven (5.4\%) cases of previous diagnosis of skin cancer. We also applied a model that enabled judging and deciding what the best nursing practice would be through the implementation of a clinical and communicative process for the workers exposed to UV radiation and pesticides with a previous diagnosis of skin cancer. This process took into account demographic, occupational and clinical characteristics and implemented clinical and communicative nursing actions, enabling positive results in terms of screening, risk communication, healthy and safe measures, follow-up, and excisions with pathological exams of two (28.5\%) workers who had previous histories of skin cancer.

The group with previous diagnosis of skin cancer was the focus of this study. The researchers, though, assumed the ethical and academic commitment to extend photographic mapping to all the workers who participated in the study and provide systematic orientation so they would be able to self-assess their skin, looking for new lesions, which can contribute to the early diagnosis of melanoma.

This commitment reveals the study's limitations and expresses the results from a restricted group and for this reason cannot be generalized to the population as a whole. Skin cancer, however, is a national and worldwide public health matter and working conditions reinforce the constant need for studies addressing and intensifying attention to rural workers exposed to UV radiation and pesticides. Hence, we suggest that nurses invest in this strategic model to multiply knowledge and interventions that combine risk theory and clinical knowledge in the public health field. 


\section{RESUMO}

Objetivo: Identificar a exposição de trabalhadores rurais à radiação solar ultravioleta e aos pesticidas; identificar casos pregressos de câncer de pele e aplicar a ação clínica e comunicativa de Enfermagem aos trabalhadores rurais com diagnóstico pregresso de câncer de pele. Método: Estudo observacional-exploratório realizado com trabalhadores rurais expostos à radiação solar ultravioleta e aos pesticidas, em área rural no extremo sul do Brasil. Utilizou-se um modelo adaptado de julgamento clínico e comunicação de risco para o desenvolvimento de intervenção aos trabalhadores com diagnóstico pregresso de câncer de pele. Resultados: Identificou-se: 123 (97,7\%) trabalhadores em condições de exposição à radiação solar ultravioleta e aos pesticidas; sete $(5,4 \%)$ com diagnóstico pregresso de câncer de pele e desses, quatro $(57,1 \%)$ apresentaram lesões potenciais de câncer de pele. Conclusão: Os resultados do estudo permitiram elucidar a conjugação entre o conhecimento clínico e comunicação de risco de câncer de pele para trabalhadores rurais.

\section{DESCRITORES}

Neoplasias Cutâneas; Trabalhadores Rurais; Riscos Ocupacionais; Enfermagem Oncológica; Competência Clínica; Comunicação em Saúde.

\section{RESUMEN}

Objetivo: Identificar la exposición de trabajadores rurales a la radiación solar ultravioleta y los pesticidas; identificar casos anteriores de cáncer de piel y aplicar la acción clínica y comunicativa de Enfermería a los trabajadores rurales con diagnóstico anterior de cáncer de piel. Método: Estudio observacional-exploratorio realizado con trabajadores rurales expuestos a la radiación solar ultravioleta y los pesticidas, en área rural en el extremo sur de Brasil. Se utilizó un modelo adaptado de juicio clínico y comunicación de riesgo para el desarrollo de intervención a los trabajadores con diagnóstico anterior de cáncer de piel. Resultados: Se identificaron: 123 (97,7\%) trabajadores en condiciones de exposición a la radiación solar ultravioleta y los pesticidas; siete $(5,4 \%)$ con diagnóstico anterior de cáncer de piel y, de esos, cuatro $(57,1 \%)$ presentaron lesiones potenciales de cáncer de piel. Conclusión: Los resultados del estudio permitieron elucidar la conjugación entre el conocimiento clínico y la comunicación de riesgo de cáncer de piel para trabajadores rurales.

\section{DESCRIPTORES}

Neoplasias Cutáneas; Trabajadores Rurales; Riesgos Laborales; Enfermería Oncológica; Competencia Clínica; Comunicación en Salud.

\section{REFERENCES}

1. Instituto Nacional de Câncer José Alencar Gomes da Silva (INCA). Estimativa 2014. Incidência de câncer no Brasil [Internet]. Rio de Janeiro; 2014 [citado 2014 dez. 13]. Disponível em: http://www.inca.gov.br/estimativa/2014/estimativa-24042014.pdf

2. American Cancer Society. Skin cancer facts [Internet]. Atlanta; 2014 [citado 29 nov. 2014]. Disponível em: http://www.cancer.org/cancer/ cancercauses/sunanduvexposure/skin-cancer-facts

3. Peters CE, Nicol A-M, Demers PA. Prevalence of exposure to solar ultraviolet radiation (UVR) on the job in Canada. Can J Public Health. 2012;103(3):223-6.

4. Loescher LJ, Janda M, Soyer HP, Shea K, Curiel-Lewandrowski C. Advances in skin cancer early detection and diagnosis. Semin Oncol Nurs. 2013;29(3):170-81.

5. Hollestein LM, van den Akker SAW, Nijsten T, Karim-Kos HE, Coebergh JW, de Vries E. Trends of cutaneous melanoma in The Netherlands: increasing incidence rates among all Breslow thickness categories and rising mortality rates since 1989. Ann Oncol. 2012;23(2):524-30.

6. Jemal A, Saraya M, Patel P, Cherala SS, Barnholtz-Sloan J, Kim J, et al. Recent trends in cutaneous melanoma incidence and death rates in the United States, 1992-2006. J Am Acad Dermatol. 2011;65(5 Suppl 1):S17-25.

7. Bauer A, Diepgen TL, Schmitt J. Is occupational solar ultraviolet irradiation a relevant risk factor for basal cell carcinoma? A systematic review and metanalysis if the epidemiological literature. Br J Dermatol. 2011;165(3):612-25.

8. Schmitt J, Diepgen TL. Occupational skin cancer due to UV-irradiation: analyses of notified cases as "virtually-certain" occupational disease in Germany between 2005 and 2011. J Dtsch Dermatol Ges. 2014;12(6):491-7.

9. Kearney GD, Xu X, Balanay JAG, Becker AJ. Sun safety among farmers and farmworkers: a review. J Agromedicine. 2014;19(1):53-65.

10. Lansbury L, Bath-Hextall F. What's new in skin cancer? An evidence-based update. Dermatol Nurs. 2012;11(1):33-9.

11. Sursu S, Fitzgerald EF, Bloom MS, Boscoe FP, Carpenter DO, Haase RF, et al. Occupational exposure to arsenic and risk of nonmelanoma skin cancer in a multinacional European study. Int J Cancer. 2013;133(9):2182-91.

12. Dennis LK, Lynch CF, Sandler DP, Alavanja MC. Pesticide use and cutaneous melanoma in pesticide applicators in the agricultural health study. Environ Health Perspect. 2010;118(6):812-7.

13. Sheppard B, Janoske M, Liu B. Understanding risk communication theory: a guide for emergency managers and communicators [Internet] College Park, MD: START; 2012 [cited 15 Oct 2014]. Available from: http://www.start.umd.edu/sites/default/files/files/publications/ UnderstandingRiskCommunicationTheory.pdf

14. Malak AT, Yildirim P, Yildiz Z, Bektas M. Effects of training about skin cancer on farmers' knowledge level and attitudes. Asian Pac J Cancer Prev. 2011;12(1):117-20.

15. Thompson C, Aitken L, Doran D, Dowding D. An agenda for clinical making and judgment in nursing research and education. Int J Nurs Stud. 2013;50(12):1720-6

16. Kearney GD, Lea CS, Balanay J, Wu Q, Bethel JW, Von Hollen H. Assessment of sun safety behavior among farmers attending a regional farm show in North Carolina. J Agromedicine. 2013;18(1):65-73.

17. Cezar-Vaz MR, Rocha LP, Bonow CA, Silva MR, Vaz JC, Cardoso LS. Risk perception and occupational accidents: a study of gas station workers in Southern Brazil. Int J Environ Res Public Health. 2012;9(7):2362-77. 
18. Cezar-Vaz MR, Bonow CA, Borges AM, Almeida MCV, Rocha LP, Severo LO. Dermatological alterations in women working on dairy farm: a case study. Ciênc Rural. 2013;43(9):1623-8.

19. Song F, Qureshi AA, Giovannucci EL, Fuchs CS, Chen WY, Stampfer MJ, et al. Risk of a second primary cancer after non-melanoma skin cancer in white men and women: a prospective cohort study. PLoS Med [Internet]. 2013 [cited 2015 Jan 17];10(4):1001433. Available from: http://www.ncbi.nlm.nih.gov/pmc/articles/PMC3635863/

20. Sobin LH, Gospodarowicz MK. TNM Classification of Malignant Tumors. Hoboken: Wiley-Blackwell; 2010.

21. Fitzpatrick TB. The validity and practicality of sun-reactive skin types I through VI. Arch Dermatol. 1988;124(6):869-71.

22. Streiner DL. Being inconsistent about consistency: when coefficient alpha does and doesn't matter. J Pers Assess. 2003;80(3):217-22.

23. Frost G, Brown T, Harding A-H. Mortality and cancer incidence among British agricultural pesticide users. Occup Med (Lond). 2011;61(5):303-10.

24. Culp K, Tonelli S, Ramey SL, Donham K, Fuortes L. Preventing heat-related illness among Hispanic farmworkers. AAOHN J. 2011;59(1):2332.

25. Feola G, Binder CR. Why don't pesticide applicators protect themselves? Exploring the use of personal protective equipment among Colombian smallholders. Int J Occup Environ Health. 2010;16(1):11-23.

26. Lee C, Duffy SA, Louzon SA, Waltje AH, Ronis DL, Redman RW, et al. The impact of sun solutions educational interventions on select health belief model constructs. Workplace Health Saf. 2014;62(2):70-9.

27. Gomes J, Parente J, Ferreira L, Viana I, Vale E. Melanoma maligno associado a nevo melanocítico. Rev SPDV [Internet]. 2011 [citado 2015 jan. 17];69(3):413-20. Disponível em: http://revista.spdv.com.pt/index.php/spdv/article/viewFile/77/75

28. Weatherhead S, Haniffa M, Lawrence C. Melanomas arising from naevi de novo melanomas - does origin matter? Brit J Dermatol. 2007;156(1):72-6. 